\author{
senior brig. Jan Krynicki, Ph.D ${ }^{a) *}$ \\ a) National Chaplain to firefighters / Kapelan Krajowy Strażaków \\ *Autor korespondencyjny / Corresponding author: parafia@bl-karolina.eu
}

\title{
The Ethos of St. Florian's knights
}

\section{Etos rycerzy św. Floriana}

\begin{abstract}
Objective: The presentation of preliminary considerations on the ethos of the profession of firefighter

Background: In addition to appropriate procedures and standards, the competences of persons who create an institution are an essential element of their good functioning. In the context of the profession of firefighter, which serves an important social mission, axiological competences, which properly condition the effectiveness of all other competences, are taking on particular significance. The shaping of the ethos of duty, which determines its model and aspirations, is their source and point of reference. One should note the important place of valorisation of the ethos of firefighter among the most important factors which build the potential of this profession

The correlation between work and living in accordance with the moral rules of individuals and professional groups is determined by the term "ethos". This notion became especially important during the dynamic development of knighthood. It became, in a sense, a synonym for a set of moral concepts attitudes and behaviour. It highlights the unconditional devotion to the undertaken obligations. Ethos is something more than adopting a specific attitude which is highly regarded in moral terms. It approximates something which can be regarded as typical morals of an individual and even more closely resembles the social norm constituting an indicator of average moral behaviour of the members of the group in specific historical circumstances. The level of firefighter's ethos, therefore, ultimately reflects the level of average moral behaviour of individual representatives of this service. Professional ethos is never shaped over a short period of time. It is often created slowly, with specific effort, by entire generations. One can indicate here an incredibly strong interrelation. Members of a given professional group not only establish the ethos, they are moulded by it into morally adult people through their work and lifestyle. Only by actually becoming involved in the implementation of ethos can one build a model lifestyle, which invariably, in the case of the profession of firefigher, is based on inner strength, courage, sacrifice and professional competence.

Conclusions: The effective pursuit of the profession of firefighter must have its axiological foundation. Therefore, shaping the ethos of the knights of St. Florian should be regarded as an important element of the theory and pragmatics of this profession.
\end{abstract}

Keywords: ethos, firefighter, morality, ideal, values, duty

Received: 20.08.2018; Reviewed: 29.08.2018; Accepted: 28.06.2019;

Author's ORCID ID: https://orcid.org/0000-0002-5597-8423;

Please cite as: SFT Vol. 53 Issue 1, 2019, pp. 188-196, https://dox.doi.org:10.12845/sft.53.1.2019.12;

This is an open access article under the CC BY-SA 4.0 license (https://creativecommons.org/licenses/by-sa/4.0/)

\section{ABSTRAKT}

Cel: Zaprezentowanie wstępnych rozważań nad etosem zawodu strażaka.

Wprowadzenie: Obok właściwych procedur i standardów, zasadniczym elementem dobrego funkcjonowania wszelkich instytucji pozostają kompetencje tworzących je osób. W kontekście profesji strażaka, będącej ważną misją społeczną, szczególnej wagi nabierają kompetencje aksjologiczne, warunkujące właściwie efektywność wszelkich innych. Za ich źródło i punkt odniesienia uznać trzeba kształtowanie etosu służby, określającego jej model i aspiracje. Wśród najważniejszych czynników budujących potencjał zawodu strażaka należy dostrzec też istotne miejsce dla waloryzacji etosu tej służby. Korelacja pracy zawodowej z życiem w zgodzie z zasadami moralnymi jednostek i grup zawodowych odnajduje swój wyznacznik w terminie „etos”. Pojęcie to nabrało szczególnego znaczenia w czasach rozwoju rycerstwa. Stało się poniekąd synonimem zbioru moralnych idei, postaw i zachowań. Podkreśla ono bezwzględną wierność podjętym zobowiązaniom. Etos jest czymś więcej niż przyjęciem określonej, co więcej moralnie wysoko ocenianej postawy. Zbliża się on do czegoś, co można określić typową obyczajowością jednostki, a jeszcze bardziej do normy społecznej stanowiącej wskaźnik przeciętnego postępowania moralnego członków grupy w określonych warunkach dziejowych. Poziom etosu strażaka odzwierciedla więc ostatecznie poziom przeciętnego moralnego postępowania poszczególnych adeptów tej służby. Etos zawodowy nie powstaje nigdy na przestrzeni krótkiego okresu. Nierzadko tworzą go powoli, z określonym wysiłkiem, całe pokolenia. Można w tym miejscu mówić o niezwykle silnej relacji zwrotnej. Nie tylko etos konstytuowany jest przez członków danej grupy zawodowej. Także sami członkowie tej grupy grupa poprzez swoją pracę czy styl życia, są przez niego 
kształtowani na dojrzałe moralnie osoby. Dopiero dzięki rzeczywistemu zaangażowaniu się w realizację etosu buduje się wzorcowy styl życia, niezmiennie w przypadku zawodu strażaka, oparty na: sile ducha, męstwie, poświęceniu oraz zawodowej kompetencji.

Wnioski: Efektywne realizowanie zawodu strażaka musi mieć swoją podbudowę aksjologiczną. Kształtowanie etosu rycerzy św. Floriana uznać należy więc za ważny element teorii i pragmatyki tego zawodu.

Słowa kluczowe: etos, strażak, moralność, ideał, wartości, służba

Przyjęty: 20.08.2018; Zrecenzowany: 29.08.2018; Zatwierdzony: 28.06.2019;

Identyfiktor ORCID autora: https://orcid.org/0000-0002-5597-8423;

Proszę cytować: SFT Vol. 53 Issue 1, 2019, pp. 188-196, https://dox.doi.org:10.12845/sft.53.1.2019.12;

Artykuł udostępniany na licencji CC BY-SA 4.0 (https://creativecommons.org/licenses/by-sa/4.0/).

\section{Background}

Even the most effective procedures, standards and structures will not ensure good functioning of institutions created by people if they are not implemented by individuals competent in various dimensions. The "moral space", shaped by individuals and whole societies, is one of the fundamental elements constituting "human resources". Having assumed that axiological competences are necessary or even the most important in the shaping of appropriate professional predispositions, this thesis should be applied even more strongly to the profession in which one can refer to calling, due to its importance. Firefighting is surely such a profession, which is marked by the moral context in innumerable areas. It is impossible to imagine a professional firefighter devoid of appropriate moral competences. The title of this article references the notion of knights of St. Florian, which has a long tradition. This patron saint of firefighters, a Roman legionary who lived in the early 4 th century could not accept being the witness of the suffering of Christians, fellow believers, and went to Lauriacum (now Lorch in Austria) to help them. There, he was captured and drowned in the Enns after refusing to bow to Roman gods, on 4 May 304. Had Florian not interfered in the affairs of Christians, had he not revealed his faith, he would have avoided a martyr's death. He made a different choice, however, as he gave his life for the religion and his brothers in faith. A parallel can be drawn between St. Florian and the firefighter, who departs to partake in operations and makes a decision to help other people risking his/her health and often life. When firefighting brigades started to form in the second half of the 19th century in the Polish part of Galicia, they adopted the symbol to be presented on their banners from Austrian firefighters. From this point in time, Polish firefighters started to be called 'St. Florian's knights' or, in short, Florians. The aim of this article is to outline the ethos of the knights of St. Florian, the shaping of which appears as an important factor in the effectiveness of professional and volunteer firefighters.

\section{Wprowadzenie}

Nawet najbardziej efektywne procedury, standardy, struktury nie zapewnią dobrego funkcjonowania tworzonych przez ludzi instytucji, jeśli nie będą wdrażane przez osoby kompetentne, $i$ to $w$ różnych wymiarach. Jednym z zasadniczych elementów konstytuujących „zasoby ludzkie” jest kształtowana przez poszczególne jednostki i całe społeczeństwa „przestrzeń moralna". Uznając kompetencje aksjologiczne za niezbędne, a nawet najważniejsze w kształtowaniu właściwych predyspozycji zawodowych, stwierdzenie to należy odnieść z jeszcze większym przekonaniem do profesji, w której odwołujemy się do powołania, ze względu na jej rangę. Taką właśnie jest bez wątpienia zawód strażaka, który ewidentnie nacechowany jest, w niezliczonych obszarach, kontekstem moralnym. Nie sposób wyobrazić sobie profesjonalnego strażaka pozbawionego właściwych moralnych kompetencji. W tytule artykułu pojawia się odniesienie do mającego długoletnią tradycję określenia rycerzy św. Floriana. Ten święty patron strażaków, legionista rzymski, żyjący na początku IV wieku, nie mógł pogodzić się z tym, że chrześcijanie, jego współwyznawcy, cierpią, i dlatego udał się do miasta Lauriacum (obecnie Lorch w Austrii), aby im pomóc. Tam został schwytany, a gdy odmówił złożenia pokłonu rzymskim bogom, utopiono go w rzece Enns, 4 maja 304 roku. Gdyby Florian nie ingerował w sprawy chrześcijan, nie ujawnił swojej wiary, uniknąłby męczeńskiej śmierci. Dokonał jednak innego wyboru - oddał życie za religię i swoich braci. Można zauważyć w tym miejscu paralelę do strażaka, który jako rycerz św. Floriana, wyjeżdżając do akcji i podejmując decyzję o pomaganiu innym ludziom, naraża zdrowie, a nierzadko i życie. Kiedy w drugiej połowie XIX wieku w polskiej części Galicji formowały się straże, przejęły one wzór symbolu na sztandary od strażaków austriackich. Odtąd właśnie strażaków polskich zaczęto nazywać rycerzami św. Floriana lub krótko florianami. Celem artykułu jest zarysowanie kwestii etosu rycerzy św. Floriana, którego kształtowanie jawi się jako ważny czynnik efektywności zawodowej i ochotniczej służby pożarnej. 


\section{The concept of professional ethos}

The correlation between work and living in accordance with the moral principles of individuals and professional groups is found in "ethos". This notion proved to be especially important during the dynamic development of knighthood. It became, in a sense, a synonym for a set of moral concepts, attitudes and behaviour. It highlights the unconditional devotion to the undertaken obligations. [1]. This field is so extensive that it is difficult to hold discourse on this issue. When referring to the definition of ethos, it is possible to attempt to formulate its constituents. Given the existential and moral context, the ethos of profession of firefighter is fulfilled in the function and duties towards the society of this service.

In contrast to the broader and often used concept of "ethics", the term "ethos" is not used only to describe the activities of individuals. As a rule, ethos refers to social and professional groups, although it obviously translates into the life of individuals and must determine them to some extent. It is impossible to talk about the ethos of a profession, also of a firefighter, if it was not applied by the greatest possible number of individuals included in the group [2]. Individual ethos, in synthetic terms, first and foremost consists in duplicating the traits characteristic of the ethos of a given social group. Ethos is the adopted and pursued lifestyle of a given community and its preferred hierarchy of values, which is formulated directly or can be inferred from human behaviour [3].

S. Witek rightly differentiates the understanding of ethos as the expression of real possibilities from ideal trends in behaviour of individual people performing specific work [4]. Despite this, in the second meaning he sees the whole point of shaping and realising ethos. Therefore, ethos means that which is ideal and exemplary in relation to a given social or professional group. It includes the standards and values, as well as the entirety of interpersonal relations as well as those between employees. Ethos is also associated with an appropriate attitude, personality and clear moral attitude. Differing from the usually adopted customs and paradigms, even those acknowledged by most people, ethos transcends the sphere of mediocrity, general approval and the rule of minimising requirements. Importantly, ethos is much more than just adopting a specific, highly regarded in moral terms, attitude. As opposed to attitude, its full manifestation occurs when, strongly rooted in a community, it becomes a sort of monolith which cannot be uprooted. Ethos implements a conventionally adopted system of moral standards, as an attempt at interpreting moral natural law and in consequence of a hierarchy of values adopted in a specific group. It approximates something which can be regarded as typical morals of an individual and, even more closely, resembles the social norm constituting an indicator of average moral behaviour of the members of the group in specific historical circumstances. The level of firefighter's ethos, therefore, ultimately reflects the level of average moral behaviour of individual representatives of the fire service. Thus, it either increases or decreases according to the hierarchies of values adopted by them and applied while on and off duty [5].

\section{Pojęcie etosu zawodowego}

Korelacja pracy zawodowej z życiem w zgodzie z zasadami moralnymi jednostek i grup zawodowych odnajduje swój wyznacznik w terminie „etos". Pojęcie to nabiera szczególnego znaczenia w czasach rozwoju rycerstwa. Stało się poniekąd synonimem zbioru moralnych idei, postaw i zachowań. Pojęcie to podkreśla bezwzględną wierność podjętym zobowiązaniom. [1]. Przestrzeń ta jest tak szeroka, że prowadzenie dyskursu w tej kwestii jest utrudnione. Odnosząc się do definicji etosu, można jednak próbować formułować konstytuujące go elementy. Ze względu na kontekst egzystencjalno-moralny etos zawodu strażaka jest realizowany w ramach tej służby zadań oraz funkcji względem społeczeństwa.

W odróżnieniu od szerszego i często stosowanego pojęcia "etyka”, określenia „etos" nie stosuje się jedynie do opisu działań poszczególnych jednostek. Etos z zasady odnosi się do grup społecznych i zawodowych, choć w oczywisty sposób posiada przełożenie na życie poszczególnych jednostek i musi je w jakimś stopniu warunkować. Nie sposób mówić o etosie zawodu, również i strażaka, jeśli nie byłby realizowany przez możliwie największą liczbę jednostek go współtworzących [2]. Etos indywidualny, syntetycznie rzec ujmując, w pierwszym rzędzie polega na powielaniu cech właściwych dla etosu określonej grupy społecznej. Etos to przyjęty, ale i realizowany styl życia danej społeczności, preferowana przez nią hierarchia wartości, formułowana wprost lub dająca się wywnioskować z ludzkich zachowań [3].

S. Witek słusznie rozgranicza rozumienie etosu jako wyrazu realnych możliwości od idealnych tendencji postępowania poszczególnych ludzi realizujących określoną pracę [4]. Mimo to w tym drugim znaczeniu widzi pełny sens kształtowania i realizowania etosu. Etos oznacza więc przede wszystkim to, co idealne, wzorcowe w odniesieniu do danej grupy społecznej lub zawodowej. Zawierają się w nim normy i wartości, a także całokształt stosunków międzyludzkich i relacji pomiędzy pracownikami. Z etosem wiąże się również odpowiednie usposobienie, właściwy charakter, jednoznaczna postawa moralna. Odbiegając od zazwyczaj przyjmowanych zwyczajów i paradygmatów, nawet tych uznanych przez większość, etos przekracza sferę przeciętności, ogólnej aprobaty i kierowania się zasadą minimalizacji wymagań. Co ważne, etos jest czymś znacznie więcej niż jedynie przyjęciem określonej, i to nawet moralnie wysoko ocenianej postawy. W odróżnieniu od postawy uwidacznia się w pełni dopiero wówczas, gdy silnie zakorzeniony w społeczności, staje się czymś w rodzaj monolitu nie do naruszenia. Etos realizuje przyjęty konwencjonalnie układ norm moralnych, będąc próbą interpretacji moralnego prawa naturalnego i konsekwencją przyjętej w określonej grupie społecznej hierarchii wartości. Zbliża się on do czegoś, co można określić typową obyczajowością jednostki, a jeszcze bardziej do normy społecznej stanowiącej wskaźnik przeciętnego postępowania moralnego członków grupy w określonych warunkach dziejowych. Poziom etosu strażaka odzwierciedla więc ostatecznie poziom przeciętnego moralnego postępowania poszczególnych adeptów tej służby. Rośnie więc albo maleje, adekwatnie do przyjmowanych i realizowanych przez nich w trakcie służby, a także i poza nią hierarchii wartości [5]. 
Ethos is obviously very closely correlated with conscience and it is difficult to properly discuss it if one would want to ignore its role in shaping the moral life of man. What is important, ethos may differ from customs and moral standards which evoke moral obligations in the conscience of individuals. A crucial element here is the duplication of traits characteristic of the ethos of a specific social group under distinct historical and cultural conditions. It is worth noting that the term "ethos" should not be used, even though it sometimes is, in a clearly negative moral sense, as when speaking about the "ethos" of thieves. Since the role of ethos is to form moral perfection of man, especially in relation to professional life, it needs to be based on objective values and should refer to them. The appearance, functioning and survival of ethos, even despite the strong variability of its secondary characteristics, is possible thanks to the constant needs of man and the social framework and forms of their implementation [5].

What is equally important, ethos should not be identified with attitudes imposed by a specific social or political authority and regarded by it as the only right ones. Ethos usually emerges naturally and is accepted by individuals as part of a complex socialisation process [6]. Ethos must not be identified with short-term and revolutionary activities which have been imposed from the top. It should be understood as a set of specific behaviours and values, generally accepted and regarded as positive, rooted in a given community for a longer period of time. True ethos, also professional one, is never shaped over a short period of time. Often, entire generations are needed to establish it, creating it slowly and with the necessary effort. The presence of a very strong feedback should be noted in this respect. Indeed, members of a given professional group not only create the ethos, but by implementing it they are, to some extent, moulded by it into fully morally mature individuals through their work and lifestyle. One should not forget, however, the often fundamental difference between the normative rules constituting various obligations and behaviours or rules actually considered and effected in a given community. This situation results in understandable dissonance between the often lofty ethos and the not always edifying practice of everyday, also professional, life. One can consider it a kind of space in which, through appropriate formation, ethos is formed at the level of individuals and broader communities.

From the perspective of reflection inspired by the Catholic faith it is worth referring in this context to the Evangelical Sermon on the Mount (Matthew 5:1-12), which captures the essence of Christian ethos. This is not a postulate of some structural or revolutionary transformation of the society, economy and politics, but a call for personal reformation of man and following the steps of Christ in a given social context [7]. The issue of the measure of moral capacity of man should be regarded as an important element determining the crux of Christian ethics. After all, it is difficult not to notice that contesting ethical principles and standards is often associated with the conviction that they are too demanding, inadequate, for example, to the human moral condition. Even if one were to agree with such a train of thought, since the ethical ideal almost always exceeds
Etos w oczywisty sposób bardzo ściśle skorelowany jest z sumieniem i trudno właściwie o nim mówić, jeśli chciałoby się jego rolę w kształtowaniu życia moralnego człowieka pominąć. Etos może także różnić się, co ważne, od zwyczaju i norm moralnych, które wywołują powinność moralną w sumieniu poszczególnych ludzi. Zasadniczym elementem jest tu powielanie przez niego cech właściwych dla etosu określonej grupy społecznej w konkretnych warunkach historyczno-kulturowych. Warto przy tym podkreślić, iż nie należy używać terminu „etos” (choć czasem tak się czyni) w sensie moralnie wyraźnie negatywnym, jak wtedy, gdy mówi się np. o "etosie" złodzieja. Skoro rolą etosu jest formowanie moralnej doskonałości człowieka, zwłaszcza w odniesieniu do życia zawodowego, to musi on bazować na wartościach obiektywnych i do nich się powinien odwoływać. Zaistnienie, funkcjonowanie, a przede wszystkim przetrwanie etosu, nawet mimo silnej zmienności jego cech drugorzędnych, możliwe jest dzięki stałym potrzebom człowieka oraz społecznym ramom i formom ich realizacji [5].

Etosu nie należy, co równie istotne, utożsamiać z poglądami czy też postawami narzucanymi przez określoną władzę społeczną czy polityczną, uznanymi przez nie za jedyne słuszne. Etos powstaje zazwyczaj w sposób naturalny i przyjmowany jest przez jednostki w ramach skomplikowanego procesu socjalizacji [6]. Etosu nie można też utożsamiać z doraźnymi i mającymi rewolucyjny charakter działaniami, narzuconymi odgórnie. Przez etos rozumieć trzeba bowiem zbiór określonych zachowań i wartości, ogólnie akceptowanych i uznawanych za pozytywne, utrwalanych w danej społeczności przez dłuższy czas. Rzeczywisty etos, także zawodowy, nie powstaje nigdy na przestrzeni krótkiego okresu. Nierzadko do jego stworzenia potrzebne są całe pokolenia, konstytuujące go powoli, z odpowiednim wysiłkiem. Należy zwrócić uwagę na istnienie w tym zakresie niezwykle silnej reakcji zwrotnej. Nie tylko bowiem etos tworzony jest przez członków danej grupy zawodowej, ale i oni niejako, realizując etos, poprzez swoją pracę czy styl życia, są przez niego kształtowani na w pełni dojrzałe moralnie osoby. Nie wolno oczywiście pomijać tego, iż istnieje często zasadnicza różnica pomiędzy kategorią normatywnych reguł stanowiących różne powinności a zachowaniami czy regułami faktycznie uwzględnianymi i realizowanymi w danej społeczności. Sytuacja ta rodzi zrozumiały dysonans pomiędzy stawianym etosem a nie zawsze szczególnie budującą praktyką codziennego życia, w tym zawodowego. Można tu mówić o swoistej przestrzeni, w ramach której, poprzez właściwie prowadzoną formację, na poziomie jednostek i szerszych społeczności, kształtuje się etos.

Z punktu widzenia refleksji inspirowanej religią katolicką warto również, i w tym kontekście, odnieść się do ewangelicznego Kazania na Górze (Mt 5, 1-12), które odsłania treść etosu chrześcijańskiego. Nie mamy tu do czynienia z postulatem jakiegoś strukturalnego czy rewolucyjnego przekształcenia społeczeństwa, gospodarki i polityki, lecz domaganiem się przede wszystkim osobistego nawrócenia człowieka oraz naśladowania Chrystusa w danym kontekście społecznym [7]. Za istotny element wyznaczający samo sedno etyki chrześcijańskiej uznać trzeba kwestię miary moralnych możliwości człowieka. Trudno przecież nie zauważyć że, kontestacja zasad i norm etycznych często wiąże się właśnie z przekonaniem, iż są one zbyt wymagające, nieadekwatne choćby do poziomu ludzkiej kondycji moralnej. Nawet jeśli jednak zgodzić się z takim tokiem 
its practical implementation, it should not lead to a conclusion that this ideal is inadequate to man or even harmful [8]. As life experience dictates, every activity can be performed better or worse and produce various results; it is, however, the effort made which strives to reach a specific ideal or model, and this is usually only partly possible.

\section{The dynamic nature of ethos}

As justly noted by A. Maclntyre, an important contemporary philosopher, every man is an ethicist, as long as he reflects on his own and other people's behaviour [9]. Rationality, which characterises every human being, is connected with the ability or even obligation to contemplate on the moral standards one accepts as well as, and more importantly, on the choices made in respect of morality, especially those demonstrating human weakness. As accurately indicated by W. Granat, the notions of $\sin$ and grace, by lending tremendous moral strength to human existence, contributed to European culture being characterised by the greatest dynamism for centuries [10]. One of these elements which distinguishes or actually makes man radically different from other beings is the multifaceted striving for perfection. Man is the kind of being which, if fully exercising its rationality and willpower, is never completely satisfied with itself. This is because man is aware of his personal development being virtually limitless. This striving for perfection characterises mainly morality which constitutes the central element of human personality. Professional life, which in contemporary times appears to create a living environment alternative to the family environment, is invariably a factor which creates a crucial framework for human morality. One would find it difficult not to notice that professional work, often being the most important reference point for many individuals, also appears to set the foundations of their moral perfection or lack thereof.

The development of human skills is always based on subjective potentials which are to some extent modified and dynamised by the objective ideal. The ideal alone, however, devoid of an internal foundation, can easily evolve towards dramatic tyranny of expectations with no possibility to meet them. Because of the temptation of minimalism and mediocrity, the potential of man striving for ideal cannot be fully realised. A life led in accordance with moral principles can be likened to a sort of "art" based on interaction between the ideal and capabilities. Man shapes himself on the basis of who he his, what he knows about himself and what he can do with that knowledge. The frequent doubts as to the possibility of realising the moral ideal, which can be observed today, have their origin mostly in the domination of pessimistic anthropology, which focuses on human weaknesses and searching for motives to justify them. This anthropology, often detached from God, largely marginalises in practice the possibility of overcoming human limits in respect of personal development and improvement. Along with the decreasing influence of Christian optimistic anthropology, rozumowania, (wreszcie ideał etyczny niemal zawsze przewyższa poziom jego realizacji w praktyce), to nie powinno to prowadzić do wniosku, iż ideał ten miałby być nieadekwatny dla człowieka czy też nawet szkodliwy [8]. Wprawdzie, zgodnie z życiowym doświadczeniem, każdą czynność można realizować gorzej lub lepiej czy też osiągać w czymś różne wyniki, to jednak podejmowanemu wysiłkowi przyświeca dążenie do pewnego ideału bądź wzoru, który przeważnie jedynie częściowo zostaje zrealizowany.

\section{Dynamiczny charakter etosu}

Jak słusznie zauważa jeden z ważnych współczesnych filozofów A. Maclntyre, każdy człowiek jest etykiem, o ile tylko zastanawia się nad swoim i cudzym postępowaniem [9]. Z charakteryzującą każdy byt ludzki racjonalnością wiąże się zdolność, a właściwie powinność refleksji, zarówno nad akceptowalnymi przez siebie normami moralnymi, jak i co ważniejsze, nad dokonywanymi wyborami w obszarze moralności, zwłaszcza tymi uwidaczniającymi ludzką słabość. Jak trafnie zauważył W. Granat, pojęcia grzechu i łaski, dając wielką siłę moralną egzystencji ludzkości, przyczyniły się do tego, że to właśnie kultura europejska przez całe wieki odznaczała się największym dynamizmem [10]. Jednym z tych elementów, który wyróżnia człowieka spośród innych bytów, a właściwie radykalnie go od nich odróżnia, jest bowiem jego wieloaspektowe dążenie do doskonałości. Człowiek jest bytem, który jeśli w pełni korzysta ze swojej racjonalności i potęgi swojej woli, nigdy nie jest w pełni z siebie zadowolony. Zdaje sobie bowiem sprawę, że jego osobowy rozwój właściwie nie zna kresu czy ograniczeń. To dążenie do perfekcji charakteryzuje przede wszystkim moralność, stanowiącą centralny element ludzkiej osobowości. Czynnikiem, który tworzy niezwykle istotne ramy dla ludzkiej moralności jest niezmiennie życie zawodowe, które w warunkach współczesności zdaje się tworzyć alternatywne względem rodzinnego środowisko życia. Trudno nie zauważyć, iż praca zawodowa, nierzadko stanowiąc najważniejszy punkt odniesienia dla wielu jednostek, zdaje się też wytyczać zręby jego moralnej doskonałości bądź też jej braku.

Rozwój ludzkich umiejętności dokonuje się zawsze na bazie subiektywnych potencjałów, które są niejako modyfikowane i dynamizowane obiektywnym ideałem. Sam jednak ideał, pozbawiony wewnętrznej bazy, łatwo może ewoluować w kierunku dramatycznej tyranii oczekiwań bez możliwości ich spełnienia. Przez pokusę minimalizmu i przeciętności potencjał człowieka niedążącego do ideału, nie może być w pełni wykorzystany. Życie zgodne z zasadami moralnymi utożsamić można ze swoistą „sztuką”, opartą na interakcji pomiędzy ideałem a możliwościami. Człowiek tworzy siebie w oparciu o to, kim jest, co wie o sobie, i co potrafi z tą wiedzą zrobić. Częste dziś wątpienie w możliwość realizacji ideału moralnego swoją genezę znajduje przeważnie w dominacji pesymistycznej antropologii, skupiającej się na słabościach człowieka i szukaniu motywów dla ich usprawiedliwienia. Antropologia ta, często oderwana od Boga, w dużej mierze marginalizuje w praktyce możliwość przekraczania ludzkich ograniczeń w perspektywie rozwoju osoby i jej doskonalenia. Wraz ze zmniejszaniem się wpływu chrześcijańskiej, optymistycznej antropologii, coraz częściej w sferze moralności pojawiają się rozwiązania, które odrzucają 
the sphere of morality more and more often witnesses solutions which reject effort, relativising the truth and good and absolutising the freedom of the individual. As a consequence, man becomes a being which negates objective morality and resigns from effort to strive for perfection. Lack of faith in man's moral capabilities and reducing him to a being which is almost incapable of self-control, condemned to the dictate of somatic or social conditions, translates into a decline of the moral level of entire societies.

The measure of man's moral capabilities is primarily associated with the level of his spirituality and harmonious development of the faculties of the mind, will and the emotional system. The symptoms of the disintegration of correct relations between these factors result in the disruption of the inside, and thus in the weakening of its ability to evaluate, select, make good and avoid wrong [11]. Therefore, one must not agree to have man embroiled in his various weakness, doubt in the power of spirit, and discard motivation for pursuing self-transcendence. This would mean consent to ethical minimalism, deprecation of human morality and negation of ethical progress achieved by subsequent generations, which draw inspiration, first and foremost, from the moral ideals and directing the potential of a human being towards development and not towards degradation.

\section{Conclusions}

Reflection on ethos becomes evident in particular in respect of selected professional groups which enjoy the highest respect and trust: clergymen, scientists, teachers, doctors, journalists and uniformed services, including firefighters. Despite the reflection on the ethics of specific professions recently becoming immensely popular, it does not always assume the form of deeper discourse. The majority of texts on this subject are journalistic or even slogan in nature and include elements of social engineering or political language. Considerable danger in this regard can be noted not only in respect of ethos, but also the intent of those who want to introduce it. The issue of presenting ethos must be closely correlated with the high ethical level of people who want to create it. Dissonance in this regard threatens ethos itself, even if it appears to verbally refer to loft and indubitably morally positive values. Attaching significance to ethos in everyday activities should be deemed necessary, since the lack of cohesion between the canon of proposed behaviours and the actual conduct of people, especially those responsible for creating the ethos, may compromise the chances of its formation [12].

The first attempts at developing and implementing "precepts", as ethical rules were referred to at that time, which should apply to people in uniformed services, were made as early as in the Second Polish Republic. Nevertheless, attempts made in the inter-war period at introducing ethical standards which were to result in a normative document that, once popularised, could become part of ethical knowledge of members of this professional circle, were not successful. However, even the plans of developing ethical standards which would apply wysiłek, relatywizując przy tym prawdę i dobro oraz absolutyzując wolność jednostki. Człowiek staje się w konsekwencji tej sytuacji istotą negującą obiektywną moralność i rezygnującą z wysiłku dążenia do doskonałości. Brak wiary w moralne możliwości człowieka, redukowanie go do istoty niezdolnej niemal do panowania nad sobą, skazanej na dyktat uwarunkowań somatycznych czy społecznych, przekłada się na obniżanie się moralnego poziomu całych społeczeństw.

Miara możliwości moralnych człowieka związana jest przede wszystkim z poziomem jego duchowości oraz harmonijnym rozwojem władz rozumu, woli i systemu emocjonalno-uczuciowego. Symptomy dezintegracji prawidłowych relacji pomiędzy tymi czynnikami skutkują rozbiciem osobowego wnętrza, a więc i osłabieniem jego zdolności wartościowania, wybierania, czynienia dobra i unikania zła [11]. Nie można więc zgodzić się na uwikłanie człowieka w jego różne słabości, zwątpić w moc ducha, przekreślić motywację do przekraczania siebie. Oznaczałaby to zgodę na minimalizm etyczny, deprecjację ludzkiej moralności, a także zanegowanie etycznego postępu kolejnych pokoleń, który inspirowany był przede wszystkim ideałami moralnymi oraz ukierunkowaniem potencjału osoby na rozwój a nie na jej degradację.

\section{Wnioski}

Refleksja nad etosem uwidacznia się przede wszystkim w odniesieniu do wybranych grup zawodowych, powszechnie cieszących się najwyższym szacunkiem i zaufaniem: kapłanów, naukowców, nauczycieli, lekarzy, dziennikarzy oraz przedstawicieli służb mundurowych, do których zaliczyć można i strażaków. Pomimo tego, iż refleksja dotycząca etyki wykonywania danego zawodu stała się w ostatnich latach niezwykle popularna, to nie zawsze ma ona wymiar pogłębionego dyskursu. Przeważają tu raczej teksty o charakterze publicystycznym, a nawet sloganowym z elementami socjotechniki czy języka politycznego. Spore niebezpieczeństwo w tej kwestii dostrzec można nie tylko w odniesieniu do etosu, ale i intencji tych, którzy starają się go wprowadzać. Problem przedstawiania etosu musi być ściśle skorelowany z wysokim poziomem etycznym ludzi starających się go kreować. Dysonans w tej kwestii zagraża samemu etosowi, nawet wtedy jeśli zdaje się on werbalnie odwoływać do wzniosłych i moralnie bezsprzecznie pozytywnych wartości. Za konieczne uznać należy przywiązywanie wagi do etosu w codziennych działaniach, gdyż brak spójności pomiędzy kanonem proponowanych zachowań a realnym postępowaniem osób, zwłaszcza odpowiedzialnych za jego kreowanie, może przekreślić szanse na ukształtowanie takiego etosu [12].

Pierwsze próby opracowania i wdrożenia w życie "prawideł", jak wówczas nazywano zasady etyczne, które winny obowiązywać funkcjonariuszy służb mundurowych, czyniono już w okresie Drugiej Rzeczypospolitej. Tego typu norm etycznych, mających stworzyć dokument normatywny, który stałby się po upowszechnieniu, częścią etycznej wiedzy ludzi z tego kręgu zawodowego, nie udało się jednak wprowadzić w okresie międzywojennym. Już jednak same plany opracowania norm etycznych, które obowią- 
to the officers of uniformed services prove that, as seen by the then heads of these formations, they constituted an important element of work regulations and a necessary addition to rules of procedure, ordinances and orders. These plans were hindered by the outbreak of World War 2. After the war ended, all attempts at devising ethical principles for the members of the uniformed services to follow were so strongly imbued with Marxist ideology that they could not, despite some attempts at formulating them, serve their role. The issue of developing a document which would include the specific rules and ethical standards could resurface only in the new, post-1989, social and political reality [13].

Determining the firefighter's ethos in the early 21 st century in respect of formulating moral standards can be based on the perfectionist and solidarity-based spirit. Within the former approach, it is assumed that moral evaluation is made in relation to a certain standard, a perfect model. The solidarity-based direction, on the other hand, entails evaluating the morality of behaviour based on whether it exerts a just impact on the welfare of others [14]. It is easy to note that the solidarity-based and perfectionist depictions of morality in respect of formulating the rules of the professional ethics of St. Florian's knights are by no means disjunctive; on the contrary, they are largely interconnected and complement each other. The analysis of the functions which professional ethics is to serve allows one to state that it is primarily intended to promote an appropriate level of performance of a given profession, to strengthen the sense of professional duty and, at the same time, to inspire public trust in this profession. The former falls within the perfectionist direction of morality, while the latter leans towards the solidarity-based one. Moral standards can, therefore, be presented as directives for behaviour depicted in the form of dictates or prohibitions formulated on the basis of duties towards others and the perfect exemplar. Since ethics involves the studying of morality and its systematics, the author finds it justified to perceive the rules of professional ethics as a form of concretisation and, to some extent, modification of the general morality of a given profession [15]. In both these fields, one can search for the appropriate space for the shaping of the firefighter's ethos.

Searching for the right order in the reality in which we function is an invariable duty of every generation, also in the case of the profession of firefighter. When reconsigning this necessity one should not forget that this task will never be truly complete, i.e. crowned with the ultimate and unquestioned moral formula which does not evolve further, also as regards professional ethos. Every new generation of the firefighting community faces the obligation to make its own contribution, which would take into account new circumstances as well as the existential and technical specificity, to determining a convincing ethos of this profession. It is in the interest of every, also this, very specific, community, to care about developing its own standards, normative points of reference which will be passed on to younger generations. The firefighter's ethos, understood as forming models for this profession, without any doubt foster the development of the personalities of members of this profession. The importance zywałyby funkcjonariuszy służb mundurowych, świadczą o tym, iż w ocenie ówczesnych dowódców tych formacji, stanowiły one ważny element pragmatyki służbowej, niezbędny, obok regulaminów, zarządzeń i rozkazów. Plany te zakłócił przede wszystkim wybuch II wojny światowej. Po jej zakończeniu z kolei, wszelkie próby opracowania zasad etycznych, którymi mieliby kierować się funkcjonariusze różnych służb mundurowych, były tak silnie przeniknięte ideologią marksistowską, iż nie mogły, mimo pewnych prób ich formułowania, spełnić swojej roli. Sprawa opracowania dokumentu zawierającego określone zasady i normy etyczne mogła zaistnieć na nowo dopiero w nowej rzeczywistości społecznopolitycznej i gospodarczej po 1989 roku [13].

Określanie etosu strażaka na początku XXI wieku, w odniesieniu do formułowania norm moralnych, może być oparte na nurcie perfekcjonistycznym i solidarnościowym. W ramach pierwszego ujęcia przyjmuje się, że oceny moralnej dokonuje się w odniesieniu do pewnego wzorca, doskonałego modelu. Nurt solidarnościowy zakłada zaś raczej ocenę postępowania jako moralnego na podstawie tego, czy wpływa ono sprawiedliwie na dobro innych ludzi [14]. Nietrudno zauważyć, że solidarnościowe i perfekcjonistyczne ujęcie moralności w odniesieniu do formułowania zasad etyki zawodowej rycerzy św. Floriana nie są w żadnym wypadku rozłączne, przeciwnie - w dużym stopniu się zazębiają i uzupełniają. Analiza funkcji, jakie stawia się etyce zawodowej, pozwala stwierdzić, że ma ona przede wszystkim sprzyjać odpowiedniemu poziomowi wykonywania danego zawodu, wzmacniać poczucie obowiązku zawodowego, a zarazem wzbudzać zaufanie społeczeństwa do przedstawicieli tego zawodu. Pierwsza z tych funkcji pozostaje w obrębie nurtu perfekcjonistycznego moralności, druga zaś związana jest w większym stopniu z nurtem solidarnościowym. Normy moralne można więc określić jako ujęte w postaci nakazów lub zakazów dyrektywy postępowania formułowane na podstawie powinności względem innych i względem idealnego wzorca. Skoro etyka zajmuje się badaniem i systematyką moralności, to uprawnione jest zdaniem autora upatrywanie w zasadach etyki zawodowej formy konkretyzacji oraz w pewnym stopniu modyfikacji ogólnej moralności w ramach określonego zawodu [15]. Na obydwu tych polach szukać można właściwej przestrzeni dla kształtowania etosu strażaka.

Poszukiwanie odpowiedniego ładu w rzeczywistości, w której funkcjonujemy, stanowi niezmiennie zadanie każdego kolejnego pokolenia, również w przypadku profesji strażaka. Dostrzegając tę konieczność, nie można przy tym zapomnieć, iż zadanie to nie zostanie tak naprawdę nigdy zakończone, to znaczy zwieńczone ostateczną, niekwestionowaną i niepodlegającą ewolucji formułą moralną, również w odniesieniu do etosu zawodowego. Przed każdym nowym pokoleniem społeczności strażackiej staje powinność wniesienia swojego wkładu, uwzględniającego aktualne okoliczności oraz specyfikę egzystencjalną i techniczną, w ustalenie przekonującego etosu tego zawodu. W interesie każdej społeczności, również i tej, tak specyficznej, leży troska o wypracowanie własnych norm, normatywnych punktów orientacyjnych, które przekazane zostaną następnym pokoleniom. Etos strażaka, rozumiany jako stawianie pozytywnych wzorców w tym zawodzie, bez żadnych wątpliwości sprzyja formowaniu osobowości przedstawicieli tej profesji. Nie należy też pomijać roli ukazywania wzorców negatyw- 
of demonstrating negative models should not be disregarded as well, since it makes it possible to resolutely condemn any inappropriate forms of collective conduct [5].

When addressing the issue of the deontology of the profession of firefighter, it is worth noting that, in every epoch, especially given the rapidly changing and highly varied external conditions, people face the enormous challenge of shaping an ethos which would meet the new social needs and expectations. According to the author, one of the leading premises when formulating this ethos is to move away from 'morality of pressure' towards individual responsibility for one's choices. It is difficult not to notice that the impact of external determinants on human moral decisions is decreasing, even if some do not want to come to terms with this fact. Nowadays, moral life is shaped first and foremost in the context of the personal decisions of individuals. This has its positive implications, as it can obviously improve the moral self-awareness of individuals, and in this case, of those in fire service. At the same time, however, building such an ethos is also associated with a certain level of risk, since it assumes the belief that all firefighters, or at least a significant proportion of them, will be able to make a considerable intellectual and moral effort to follow it. In this context, it is, therefore, worth noting that life ethos is not necessarily an area of human freedom, opposed to heteronomous morality, but is rather a task faced by every individual who is aware of it. This ethos, as a proposal, is faced by specific moral subjects who can strive to shape an adult ethical personality, a model of their existence. For this reason, only by actually becoming involved in the implementation of ethos can one shape and recreate a morally appropriate or even exemplary lifestyle, which invariably, in the case of the profession of firefighter, is based on inner strength, courage, commitment, and professional competence.

The fundamental element of every ethos, defining in a way both its nature and practical meaning, is the formative element associated with it. In order for this educational character of ethos to be fully realised, an individual from a specific social group must be presented by the ethos with an unambiguously positive and clearly defined model of behaviour. This, obviously, does not entail that the ethos becomes "fossilised" or "frozen", failing to recognise external determinants. The firefighter's ethos can change under external living conditions and cultural aspirations of a group, but, in principle, is also characterised by certain constancy due to fairly invariable, fundamental inspirations. In such professional groups as the fire service, one can note, first and foremost, a constant reference to the same duties assigned to them, despite the drastically changing working methods. Irrespective of whether the firefighter's ethos is being realised by means of technically unsophisticated 19th century conditions or with advanced 21 st century technologies, it is always guided by the protection of the same values: human life, health and property. nych, gdyż dzięki ich ukazaniu istnieje możliwość zdecydowanego napiętnowania niewłaściwych form postępowania zbiorowego [5].

Podejmując tematykę deontologii zawodu strażaka należy również zauważyć, iż ludzie w każdej epoce, zwłaszcza w kontekście dziś tak szybko zmieniających się i niezwykle zróżnicowanych uwarunkowań zewnętrznych, stają przed ogromnym wyzwaniem kształtowania takiego etosu, który byłby w stanie sprostać nowym potrzebom i oczekiwaniom społecznym. Za jedną z wiodących przesłanek przy jego formułowaniu uznać trzeba, zdaniem autora, odchodzenie od moralności nacisku w kierunku indywidualnej odpowiedzialności za dokonywane wybory. Trudno nie zauważyć, iż wciąż zmniejsza się, nawet jeśli nie wszyscy chcą się z tym pogodzić, wpływ determinantów zewnętrznych na ludzkie decyzje o charakterze moralnym. Współcześnie kształtowanie życia moralnego dokonuje się przede wszystkim w kontekście osobistych decyzji poszczególnych jednostek. Posiada to swoje pozytywne implikacje, gdyż w oczywisty sposób może zwiększać samoświadomość moralną jednostek, w tym przypadku tych, które realizują służbę strażaka. Budowanie takiego etosu wiąże się jednak także z pewnym poziomem ryzyka, gdyż zakłada on wiarę w to, iż wszyscy strażacy, a przynajmniej ich znaczna część, podejmowania poważanego wysiłku intelektualnego oraz moralnego w tym kierunku. Warto więc $w$ tym kontekście zauważyć, iż etos życiowy nie tyle stanowi obszar ludzkiej wolności, przeciwstawnej moralności heteronomicznej, ile jest dzisiaj zadaniem stojącym przed każdym, kto jest tego świadomy. Etos ten, jako propozycja, stoi przed konkretnymi podmiotami moralnymi, mogącymi dążyć do kształtowania dojrzałej osobowości etycznej, modelu swojej egzystencji. Z tego więc względu, dopiero dzięki rzeczywistemu zaangażowaniu się w realizację etosu, kształtuje się oraz odtwarza właściwy moralnie, a nawet wzorcowy styl życia, niezmiennie w przypadku zawodu strażaka oparty na: sile ducha, męstwie, poświęceniu oraz zawodowej kompetencji.

Zasadniczym elementem każdego etosu, określającym niejako zarówno jego charakter, jak i praktyczne znaczenie, jest związany z nim element formacyjny. Aby ten wychowawczy charakter etosu mógł się w pełni zrealizować, etos ten musi ukazywać jednostce przynależnej do określonej grupy społecznej jednoznacznie pozytywny, jasno określony wzorzec postępowania. Nie chodzi przy tym o pewno rodzaju "skostnienie" czy „zastygnięcie” etosu nieuwzględniające determinantów zewnętrznych. Etos strażaka może zmieniać się pod wpływem zewnętrznych warunków życia i dążeń kulturowych grupy, ale odznacza się też z zasady pewną stałością $\mathrm{z}$ racji mało zmiennych zasadniczych inspiracji. W ramach takiej grupy zawodowej jak strażacy dostrzec można przede wszystkim niezmienne odniesienie do tych samych zadań im stawianych, pomimo diametralnie zmieniających się metod pracy. Bez względu na to bowiem, czy etos strażaka realizuje się w prymitywnych technicznie uwarunkowaniach XIX wieku, czy też zaawansowanej technologii XXI wieku, zawsze zakłada on ochronę tych samych wartości: ludzkiego życia, zdrowia i mienia. 


\section{Literature / Literatura}

[1] Czarnecki P., Marii Ossowskiej nauka o moralności, WSFiZ w Warszawie, Warszawa 2005, s. 125.

[2] Szawiel T., Etos, w: Encyklopedia socjologii, t. 1, Warszawa 1998, s. 202-203.

[3] Etos, w: Encyklopedia PWN w trzech tomach, t. 1, PWN, Warszawa 2006, s. 494.

[4] Witek S., Etos, w: Encyklopedia katolicka, t. 4, TN KUL, Lublin 1995, kolumna 1195-1196.

[5] Witek S., Etos, w: Powszechna Encyklopedia Filozofii, t. 3, Lublin 2002, s. $254-255$

[6] Lazari-Pawłowska I., Etyka. Pisma wybrane, red. P.J. Smoczyński, Ossolineum, Wrocław 1992, s. 84-91.

[7] Wichrowicz C. J., Zarys teologii moralnej w ujęciu tomistycznym, Warszawa 2016, s. 17.

[8] Olczyk M., Cnoty teologalne a miara moralnych możliwości człowieka, „Teologia i moralność" 2009, 6, s. 101.
[9] Maclntyre A., Etyka i polityka, tł. A. Chmielowski, Wyd. Naukowe PWN SA, Warszawa 2009, s. 18

[10] Granat W., Dogmatyka katolicka, t. 2, Bóg Stwórca-Aniołowie-Człowiek, Lublin 1961, s. 407

[11] Wojtyła K., Osoba i czyn, Lublin 2000, s. 284-295.

[12] Gil D., Etyka funkcjonariusza Służby Więziennej. Czy właściwa postawa funkcjonariusza może oddziaływać programowo na skazanego?, w: Zasady etyki zawodowej w służbach mundurowych, red. P. Jóźwiak, K. Opaliński, Piła 2013, s. 44.

[13] Kępa Z., Zasady etyczne podstawą działania służb mundurowych - rzeczywistość czy życzenie, w: Ku etycznym zasadom służb mundurowych, red. Z. Kępa, A. Szerauc, Płock 2009, s. 50-53.

[14] Wronkowska S., Ziembiński Z., Zarys teorii prawa, Poznań 1997, s. 82-83.

[15] Ossowska M., Podstawy nauki o moralności, Warszawa 1957, s. 352.
SENIOR BRIG. JAN KRYNICKI, PH.D. - the parish priest of the blessed Karolina Kózka Parish in Rzeszów. National Chaplain to firefighters. A graduate of Firefighting College in Kraków.
KS. ST. BRYG. DR JAN KRYNICKI - proboszcz Parafii pw. Błogosławionej Karoliny Kózki w Rzeszowie, krajowy kapelan strażaków, absolwent Szkoły Chorążych Pożarnictwa w Krakowie.
Stworzenie anglojęzycznych wersji oryginalnych artykułów naukowych wydawanych w kwartalniku „BITP. Bezpieczeństwo i Technika Pożarnicza" - zadanie finansowane w ramach umowy 658/P-DUN/2018 ze środków Ministra Nauki i Szkolnictwa Wyższego przeznaczonych na działalność upowszechniającą naukę. 